\title{
A Case of Embolotherapy Using Coils, Stents for Ruptured Carotid Artery in Rucurred Hypopharyngeal Cancer
}

\author{
Jae Eun Lee ${ }^{1}$, Jin Choon Lee ${ }^{1}$, Tae Hong Lee ${ }^{2}$ and Soo Geun Wang ${ }^{1}$ \\ ${ }^{1}$ Department of Otolaryngology-Head and Neck Surgery, ${ }^{2}$ Radiology, Pusan National University School of Medicine, Busan, Korea \\ 재발한 하인두암 환자에서 스텐트(Stent) 유치 및 코일링(Coiling)으로 치료한 경동맥 파열 1예 \\ 이재은 ${ }^{1} \cdot$ 이진춘 $^{1} \cdot$ 이태홍 ${ }^{2} \cdot$ 왕수건 $^{1}$ \\ 부산대학교 의학전문대학원 이비인후과학교실, ${ }^{1}$ 영상의학과학교실 ${ }^{2}$
}

Received April 1,2009

Accepted June 8, 2009

Address for correspondence

Soo Geun Wang, MD

Department of Otolaryngology-

Head and Neck Surgery,

Pusan National University

School of Medicine,

305 Gudeok-ro, Seo-gu,

Busan 602-739, Korea

Tel +82-51-240-7331

Fax +82-51-246-8668

E-mail wangsg@pusan.ac.kr
Carotid artery rupture in patients with squamous cell carcinoma of the head and neck is one of the most devastating complications associated with head and neck surgery. The reported incidence of carotid rupture in patients who have had a neck dissection or radiation therapy is $3-4 \%$. Because of the $40 \%$ mortality associated with this complication, many researchers have written about the methods of management regarding this problem. Carotid rupture tends to occur in patients with associated conditions such as pharyngocutaneous fistula, recurrent tumor, or radiation necrosis. Management of carotid artery rupture includes surgical ligation and endovascular treatment of ruptured artery. Many authors reported that results of endovascular therapy is better than one of exploration of the neck and ligation. We reported a case of endovascular therapy using coils, stents, and graft-stent for ruptured carotid artery in patients with recurrent hypopharyngeal cancer. Korean J Otorhinolaryngol-Head Neck Surg 2009;52:623-6

Key Words Carotid artery $\cdot$ Endovascular $\cdot$ Coil $\cdot$ Stent $\cdot$ Graft.

\section{서 론}

경동맥 파열은 두경부 편평상피암으로 수술 받은 환자에 서 발생할 수 있는 매우 치명적인 합병증 중 하나이다. 경 부곽청술을 받은 환자에 있어서 경동맥 파열의 보고된 발 생률은 약 3 4\% 정도로 드물지만 사망률은 약 $40 \%$ 정 도로 치명적이다. ${ }^{1,2)}$ 경동맥 파열은 인두피부누공 혹은 방 사선 조사 후 조직의 괴사가 발생한 경우에 주로 나타난다. 경동맥 파열에 의한 급성출혈에 대한 치료는 분리가능풍선 (detachable ballon), 코일(coil), 스텐트(stent) 등을 이 용한 혈관내 치료법이 많이 보고되고 있으나, ${ }^{3-5)}$ 분리가능 풍선이나 코일을 이용한 경동맥 폐색술은 측부순환이 충분 한 경우에도 경동맥 폐색 후 저관류에 의한 허혈성 뇌졸중 이 5 22\%에서 발생하는 것으로 알려져 있다. ${ }^{6)}$ 측부순환 이 충분하지 않아 경동맥을 폐색할 수 없는 경우에는 스텐 트를 이용한 코일색전술이나 graft-stent 설치술 등으로
경동맥의 혈류를 유지시켜 주어야 합병증을 경감시킬 수 있다.

저자들은 재발한 하인두암 환자에서 위간치술 후 발생한 인두경동맥 누공에 의한 경동맥 파열을 스텐트, 코일, graftstent를 이용하여 경동맥의 혈류를 유지하면서 출혈을 막 을 수 있었기에 문헌고찰과 함께 보고하는 바이다.

\section{증 례}

55세 남자 환자로 2005년 5월 타병원에서 조직검사상 하인두암(후윤상암)으로 진단받고, 2005년 5월부터 6월 까지 방사선 치료 $(7,000 \mathrm{cGy})$ 를 시행 받은 후 경과관찰 중 2005년 10월 갑작스런 호흡곤란 증세 보여 본원 응급실 로 내원하였다. 내원 당시 후두내시경검사상 양측 성대마비 소견을 보여 응급기관절개술을 시행하였다. 기관절개술 후 경과 관찰 중 지속적으로 인후통을 호소하여, 재발이 의심 
되는 인두후벽에서 조직검사를 시행하였다. 인두후벽에 생 긴 편평세포암종의 재발로 진단되었으며, 이전 방사선 치료 를 시행받은 타병원에서 2006년 3월 인후두전절제술 및 위 간치술(total laryngopharyngectomy with gastric pullup)을 시행받은 후 동년 4 월부터 5월까지 추가적인 방사 선 치료 $(6,000 \mathrm{cGy})$ 를 시행받았다. 방사선 치료 약 2 개월 후 갑작스런 심한 구출혈과 비출혈이 발생하여 본원 응급 실로 내원하였다. 내원시 출혈은 지속되었고, 이로 인해 수 축기 혈압이 $30 \mathrm{mmHg}$ 까지 저하되는 소견이 보여 출혈 부 위를 확인하고 혈관내 치료를 위해 혈관조영술을 시행하였다.

시술은 전신마취를 하지 않은 상태에서 시행하였고 심전 도, 동맥 산소 분압 및 혈압을 적절히 감시하였다. 경피적 접근은 오른쪽 대퇴동맥을 통해 이루어졌으며 $8 \mathrm{~F}$ sheath 를 대퇴동맥내로 삽입하였다. 8F 유도관(Guider Soft, Boston Scientific Corportion, USA) 을 좌측 총경동맥에 두고 시행한 혈관조영술에서 원위부 총경동맥에서 조영제의 혈 관외 누출이 관찰되었다(Fig. 1). 총경동맥 폐쇄술은 좌측 대뇌반구의 뇌경색의 위험이 있어 총경동맥의 혈류를 유지 하기 위해 스텐트를 이용한 코일색전술을 하기로 하고 9 $\mathrm{mm} / 40 \mathrm{~mm}$ 와 $9 \mathrm{~mm} / 50 \mathrm{~mm}$ 크기 두 개의 자가팽창형 스 텐트(Wallstent, Boston Scientific Corportion, USA)를 파열된 부위를 포함하여 근위부 내경동맥에서 원위부 총경 동맥에 걸쳐서 설치하였다. 그리고 미세도관(Prowler, Cordis Endovascular Corportion, USA)을 스텐트를 통해 혈 관이 파열된 부위로 진행시키고, 67개의 섬유코일(Tornado, Cook, USA)로 색전술을 시행하였다. 충분한 코일색전술 시 행 후에도 조영제의 혈관외 유출이 계속 관찰되어 풍선팽창 형 graft-stent(Precise RX, Cordis Corporation, Miami, USA) 를 파열된 부위에 추가로 설치하였다. 시술 후 시행한 혈관조영술에서 총경동맥의 혈류는 잘 유지되면서 조영제 의 혈관외 유출이 관찰되지 않고(Fig. 2), 수축기혈압이 30 $\mathrm{mmHg}$ 이하에서 $100 \mathrm{mmHg}$ 정도로 호전되어 시술을 마 쳤다. 대퇴동맥 천자 부위는 지혈기구(Angio-Seal, St. Jude Medical Europe, Belgium)를 이용하여 처리하였다.

3 일 후 전신마취하 좌측 경부탐색술을 시행하였다. 수술 시야에서 인두경동맥누공 및 주변조직의 괴사, 그리고 악 취의 농이 관찰되었고, 후인두 부위에서 시행한 조직의 동 결절편 조직검사상 편평세포암의 재발이 확인되었으며 척
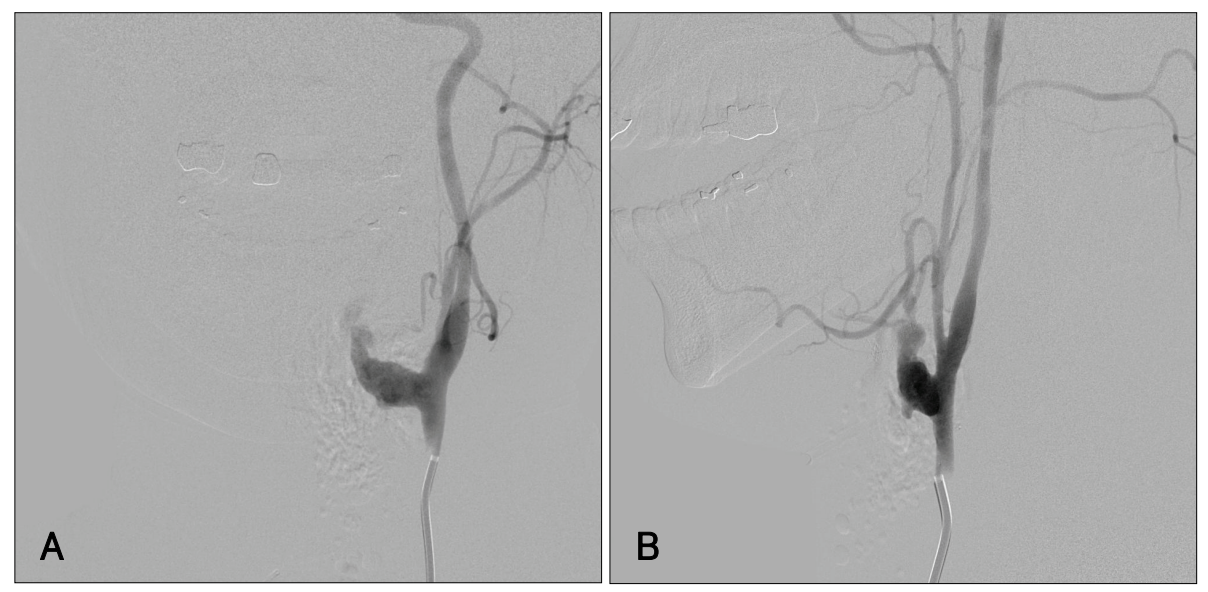

Fig. 1. Anteroposterior (A) and lateral view (B) show contrast extravasation through ruptured left distal common carotid artery.
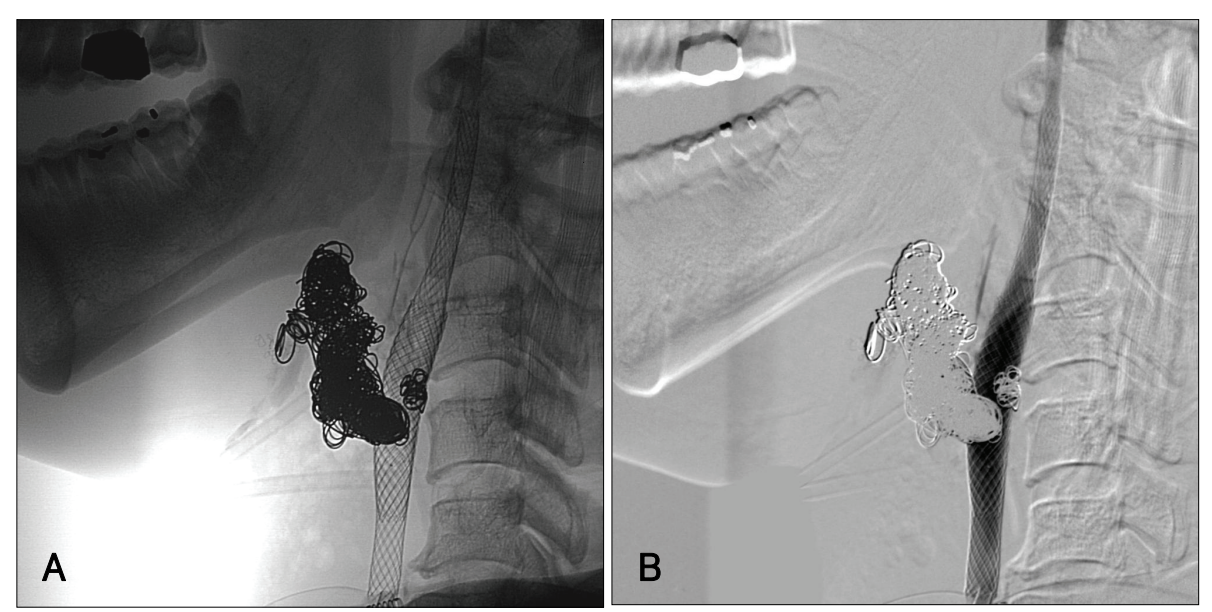

Fig. 2. Left lateral radiologic $(A)$ and angiographic (B) views after embolization using coils, stent and graft stent reveal patent common carotid artery without contrast extravasation. 

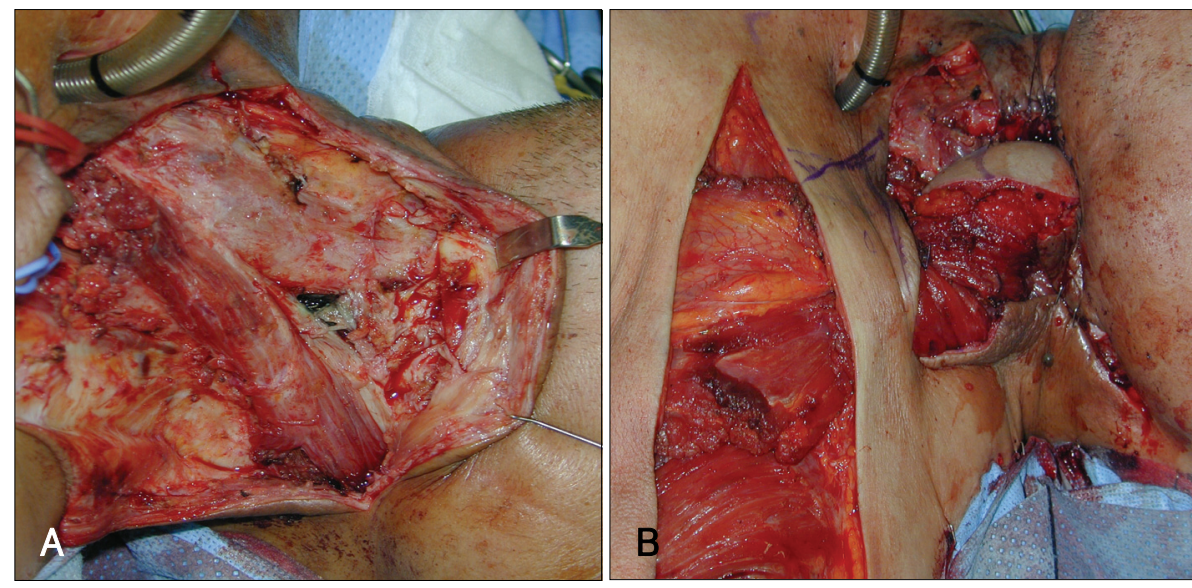

Fig. 3. After post-stent insertion 3 days, surgical neck exploration was done. There was pharyngocervical fistula and necrotic tissue (A). Left pharyngostoma formation with pectoralis major myocutaneous flap and deltopectoral flap was done (B).

추전근막을 침범하였기에 더 이상 진행을 포기하고, 경동맥 노출 부위만을 막아주기 위하여, 대흥피판 및 삼각흥근피 판(pectoralis major myocutaneous flap, deltopectoral flap)을 이용하여 인두공 (pharyngostoma)을 만들고 수술 을 종료하였다(Fig. 3).

술 후 30 일경에 유경피판 재건 부위에서 농의 배출과 함 께 괴사가 관찰되었으며 하부에 종괴의 재발이 확인되었다. 수술 60 일경 좌측 총경정맥 스텐드 삽입 부위가 유경피판 의 괴사로 재노출되었으나 출혈증상은 없었다. 환자는 수술 72 일째 다장기부전으로 사망하였다.

\section{고 찰}

경동맥 파열은 재발한 두경부암에서 발생하는 높은 사망 률을 보이는 합병증으로, 위험요소에는 방사선 치료 실패 후 구제 목적의 경부절제술, 경부림프절의 재발과 인두피부누 공, 구강피부누공, 방사선 괴사 등이 있다. 대부분의 경동맥 파열 예들은 둘 혹은 셋 이상의 위험요소를 가지고 있다. ${ }^{3,7)}$ 본 증례도 방사선 치료 후 재발된 하인두암에서 전인후두 절제술 및 위상간치술 및 추가적인 방사선 치료를 시행 받 은 후 인두피부누공이 존재한 경우이다.

경동맥 파열에 대한 치료로 수술적 결찰과 혈관내 치료 (풍선 색전술, 코일 및 스텐트를 이용한 시술) 가 시행될 수 있다. 경동맥 파열은 응급결찰이 된다고 해도 신경학적 합 병증의 위험성이 있다. Schumrick 등8)은 13 예의 응급결 찰 중 8 예가 사망하였다고 보고하였으나 예방적으로 결찰 한 6 예에서는 1 예도 사망하지 않았다고 보고하였다. Kim 등9)은 경동맥 파열 환자 13 명 중 파열로 인한 사망은 7 명 으로 사망률은 $53.8 \%$ 로 보고하였으며, 이 중 응급수술시 결찰술을 시행한 6 예 중 2 예는 결찰술 시행 전 과다 출혈 로 인하여 72 시간 이내 사망하였으며, 1 예에서는 결찰술
후 반신마비가 동반되었다고 보고하였다. 6 예 중 3 예는 재 출혈이나 신경학적 손상을 나타나지 않았다고 한다. 이러한 보고는 경동맥파열 환자에 있어서 경동맥 결찰 등의 수술 적 치료가 높은 사망률을 보이고 있으며, 응급수술은 선택 적 수술보다 더 많은 사망률을 가져왔음을 시사한다. 또한 경동맥 파열에 대한 수술적인 경부탐색술 및 경동맥 결찰 술은 전신마취 및 경동맥 조작에 따른 경동맥구 반사로 인 한 심혈관계의 불안정성의 위험이 있고, 정확한 파열 부위 를 발견하여 선택적 폐색이 힘든 경우가 많아 신경학적 후 유증 발생 가능성이 높은 것으로 알려져 있다.

경동맥 파열의 혈관내 치료법은 주로 분리가능풍선이나 코일을 이용하여 경동맥을 폐색시키는 것이다. 혈관내 치료 는 경동맥 파열에 의한 응급 상황에서 전신마취 없이 신속 한 처치가 가능하며, 정확한 출혈 부위의 확인과 치료가 동 시에 가능한 장점이 있다. Citardi 등ㄴ)은 경동맥 파열 15 명 환자에서 경동맥 결찰의 수술적 치료를 받은 3 명에서 수술 중 또는 수술 후 출혈로 2 명이 사망하였음에 비해 분 리가능풍선을 이용하여 경동맥 폐색한 12 명의 환자에서는 사망한 예가 없으며, 단 1명에서 동측 호너씨증후군(Honer's syndrome) 의 신경학적 휴우증이 남았다고 보고하 였다. 국내에서는 Nam 등미)이 경동맥 파열을 풍선 색전술 로 치료하였다고 보고하였고, Choi 등1은 경동맥 파열이 임박한 예에서 풍선색전술을 시도하였으나 후유증은 없었 다고 보고하였다. 하지만 수술적 결찰술이나 분리가능풍선 을 이용하여 경동맥을 완전 폐색할 경우 허혈성 뇌졸중의 위험이 있는 단점이 있다. 이러한 단점을 보완하기 위해 경 동맥 폐색전에 풍선으로 경동맥을 약 20 분 정도 폐색시키 고 신경학적 이상을 평가하고 있다(balloon occlusion test). 하지만 풍선폐색검사에서 신경학적 이상 소견이 발생하지 않아 경동맥을 완전 폐색을 하더라도 이후 허혈성 뇌졸중 이 5 22\%에서 발생하는 것으로 알려져 있다. ${ }^{6)}$ 본 증례는 
수축기 혈압이 $30 \mathrm{mmHg}$ 이고 많은 양의 출혈이 있는 초응 급 상황이었기 때문에 20분간의 풍선폐색검사를 시행할 수 가 없었고 우성 대뇌반구를 담당하는 좌측 총경동맥 파열 이어서 경동맥 폐색 후 뇌경색이 발생할 경우 치명적일 수 있어 경동맥을 보존하기 위해 스텐트와 코일로 치료한 경 우이다. 경동맥을 보존하기 위해 스텐트를 이용한 코일색전 술을 시행하였지만 출혈이 계속되어 추가로 graft-stent를 설치함으로써 지혈이 되었다. 저자들은 이 증례를 통해 경 동맥 파열의 치료에 있어서 경동맥을 반드시 보존해야 할 경우에는 처음부터 graft-stent로 지혈을 시도하는 것이 더 효과적일 것으로 생각되나 이에 대한 더 많은 경험과 연구 가 필요하다. 이 방법은 경동맥을 폐색하지 않고 뇌혈류를 유지함으로써 신경학적 후유증의 빈도를 낮출 수 있는 장점 이 있다.

Warren 등 ${ }^{3)}$ 은 3 명의 환자를 스텐트 유치로 급성 출혈 을 치료하였으나, 이 후 경과관찰 중 2 명의 환자는 스텐트 가 노출되거나, 궁극적으로 혈전이 발생하였다고 보고하였 다. 1 명의 환자에서는 다른 부작용은 없었으나, 시술 3 개 월 후 사망하였다. 본 증례는 스텐트와 코일 유치 후 시행 한 경부탐색술상 재발이 확인되었으나 결손부는 유경피판 으로 막아주어 재출혈은 막을 수 있었으나 다장기부전으로 2 개월 후 사망하였다. 스텐트와 코일을 이용한 치료가 경동 맥 파열에 따른 급성 출혈의 조절에 대해서는 효과적인 치 료성적을 보이고 있지만, 오염된 창상, 괴사가 진행 중인 조 직에 이물을 삽입하게 될 경우엔 여러 가지 문제가 유발될 가능성이 크다.

급성 출혈에 대한 스텐트와 코일 치료는 성공적이나, 장기 적인 결과는 아직 논란이 많아 향후 많은 연구와 임상적 시 도가 필요할 것으로 사료된다.

경동맥 파열 환자가 주로 가지는 선행인자에는 이전의 방사선 조사력, 광범위한 수술병력, 상처치유의 지연, 누공 및 감염의 존재, 암의 재발 등이 있으며, 이러한 선행인자 를 초기의 적극적인 영양공급과 혈액학적 이상의 교정으로 상처치유 및 조직의 괴사를 막는 것이 중요하다. ${ }^{4)}$ 또한 여 러 저자들은 경동맥 파열이 임박한 환자에서 이전의 여러 가지 임상증상을 통해 경동맥 파열 가능성을 예상하고 선
택적으로 수술한 경우가 응급 수술한 경우보다 결과가 좋 은 것으로 보고하고 있어, ${ }^{8,11)}$ 선행인자를 가진 환자에서 더 욱 세밀한 주의가 필요하겠다.

결론적으로 경동맥 파열의 치료는 결찰술 및 풍선 확장 술과 같이 혈류 폐쇄를 목적으로 하는 시술보다는 파열 부 위만 선택적으로 막아 폐쇄에 따른 합병증을 줄일 수 있는 방법이 환자의 삶의 질적인 면에서 우수할 것으로 생각된다.

\section{Acknowledgments}

This work was supported for 2 years by Pusan National University research grant.

\section{REFERENCES}

1) Morrisey DD, Andersen PE, Nesbit GM, Barnwell SL, Everts EC, Cohen JI. Endovascular management of hemorrhage in patients with head neck cancer. Arch Otolaryngol Head Neck Surg 1997;123 (1): 15-9.

2) Chaloupka JC, Roth TC, Putman CM, Mitra S, Ross DA, Lowlicht $\mathrm{RA}$, et al. Recurrent carotid blowout syndrome: diagnostic and therapeutic challenges in a newly recongnized subgroup of patients. AJNR Am J Neruroradiol 1999;20 (6):1069-77.

3) Warren FM, Cohen JI, Nesbit GM, Barnwell SL, Wax MK, Andersen PE. Management of carotid 'blowout' with endovascular stent grafts. Laryngoscope 2002;112 (3):428-33.

4) Citardi MJ, Chaloupka JC, Son YH, Ariyan S, Sasaki CT. Management of carotid artery rupture by monitored endovascular therapeutic occlusion (1988-1994). Laryngoscope 1995;105 (10):1086-92.

5) Chaloupka JC, Putman CM, Citardi MJ, Ross DA, Sasaki CT. Endovascular therapy for the carotid blowout syndrome in head neck surgical patients: diagnostic and managerial considerations. AJNR Am J Neuroradiol 1996;17(5):843-52.

6) Carter BS, Ogilvy CS, Putman C, Ojemann RG. Selective use of extracranial-intracranial bypass as an adjunct to therapeutic internal carotid artery occlusion. Clin Neurosurg 2000;46:351-62.

7) Medina JE. Neck Dissection. In: Bailey BJ, editor. Head and Neck Surgery-Otolaryngology. $2^{\text {nd }}$ ed. Philadelphia: Lippincott-Raven;1998. p.1563-94.

8) Shumrick DA. Carotid artery rupture. Laryngoscope 1973;83 (7): 1051-61.

9) Kim GH, Shim YS, Oh KK, Lee YS. Rupture and ligation of the carotid artery in head and neck cancers. Korean J Otolaryngol-Head Neck Surg 1992;35 (6):809-18.

10) Nam SY, Park MH, Jun HK, Nam EC. A case of management of carotid artery rupture by detachable ballon embolization. Korean J Otolaryngol-Head Neck Surg 1999;42 (1):125-8.

11) Choi EC, Kim DL, Kim SC. Elective carotid artery occlusion in impending rupture using detachable balloon embolization. Korean J Otolaryngol-Head Neck Surg 1995;38 (5) :790-5. 